\title{
Implikasi Perubahan Undang-Undang Pemerintahan Daerah Terhadap Kewenangan Tata Kelola Pemanfaatan Energi dan Sumber Daya Mineral Oleh Pemerintahan Daerah di Indonesia
}

\author{
Oleh \\ Rizky Setiawan ${ }^{1}$ \\ Program Studi Ilmu Pemerintahan \\ Fakulas Ilmu Sosial dan Ilmu Politik \\ Universitas Islam Riau \\ Risky.ip@soc.uir.ac.id
}

\begin{abstract}
Abstrak
Tulisan ini mencoba mengkaji kewenangan Pemerintahan Daerah pasca perubahan Undang-undang Pemerintahan Daerah Nomor 32 tahun 2004 ke Undang-undang Nomor 23 tahun 2014. Penyusunan tulisan ini berdasarkan kajian Kepustakaan dan Perundang-undangan. Salah satu poin penting dalam perubahan Undang-Undang Pemerintahan Daerah berkaitan dengan kewenanganPemerintahan Daerah dalam Tata Kelola Sumber Daya Mineral. Implikasi dari perubahan Undang-undang Pemerintahan Daerah diantaranya berkurangnyakewenangan Pemerintah Daerah Tinggkat II berkaitan Pemberian izin dan Pengawasan Pemanfaatan Energi dan Sumber Daya Alam yang ada di kawasan Daerah Kabupaten/kota di Indonesia. pengambilan kebijakan publik (public policy making). Energi dan Sumberdaya mineral saat ini telah memainkan peran sangat penting dalam pembangunan pereekonomian Indonesia, yang berfungsi sebagai salah satu tulang punggung penerimaan Negara. Pengelolaannya Sumber Daya Alam perlu dilakukan secara optimal, efisien, transparan, berkelanjutan dan berwawasan lingkungan, serta berkeadilan agar dapat memperoleh manfaat sebesar-besar bagi kemakmuran rakyat secara berkelanjutan.
\end{abstract}

Kata Kunci : Kebijakan, Kewenangan, Pemerintahan Daerah dan Tata Kelola

\begin{abstract}
This paper attempts to examine the authority of the Regional Government following the amendment of the Regional Government Law Number 32 of 2004 to Law No. 23 of 2014. The compilation of this paper is based on a review of Library and Legislation. One of the important points in the amendment of the Lawon Regional Government relates to the authority of the Regional Government in the Management of Mineral Resources. The implications of the amendments tothe Law on Regional Government include the decreasing authority of the Government of Tinggua II related to the granting of permits and supervision of the utilization of energy and natural resources in the area of regencies / cities in Indonesia. public policy making (public policy making). Energy and Mineral Resources have now played a very important role in the development of the
\end{abstract}


Indonesian economy, which serves as one of the backbone of state revenue. The management of Natural Resources needs to be done optimally, efficiently, transparently, sustainably and environmentally sound, and equitable in order to gain the greatest benefit for the people's sustainable prosperity.

Keywords: Policy, Authority, Local Government and Governance

\section{Latar Belakang}

Sejarah membuktikan bahwa pengelolaan sumberdaya alam (SDA) selalu menjadi bagian dari pembentukan dan perubahan peraturan perundang-undangan atau kebijakan mengenai desentralisasi.

Hal tersebut terjadi sekalipun sejumlah sektor sumberdaya alam yang vital seperti energi dan sumberdaya mineral, kehutanan dan perikanan dan kelautan, tidak terkait dengan pelayanan dasar atau bahkan urusan pemerintahan yang bersifat wajib. Penempatan pengelolaan SDA dalam kebijakan desentralisasi karena itu, tidak terlepas dari

kedudukan SDA sebagai sumberdaya yang mendatangkan kemampuan finansial negara untuk menyelenggarakan pelayanan dasar.

Sebagai produk politik, SDA dalam peraturan perundangundangan mengenai desentralisasi juga merupakan hasil dari kompromi dalam proses pengambilan kebijakan publik (public policy making). Energi dan Sumberdaya mineral sejak masa awal berdirinya Republik Indonesia sampai dengan saat ini telah memainkan peran sangat penting dalam pembangunan pereekonomian Indonesia, yang berfungsi sebagai salah satu tulang punggung penerimaan Negara. Prosentasi penerimaan negara dari sektor ini masih sekitar 30\% dari total penerimaan bidang lainnya.
Mengingat minerba sebagai kekayaan alam yang terkandung di

dalam bumi merupakan sumber daya alam yang tak terbarukan, pengelolaannya perlu dilakukan secara optimal, efisien, transparan, berkelanjutan dan berwawasan lingkungan, serta berkeadilan agar dapat memperoleh manfaat sebesarbesar bagi kemakmuran rakyat secara berkelanjutan.

Untuk memberikan landasan hukum bagi langkah-langkah pembaruan dan penataan kembali kegiatan pengelolaan dan pengusahaan minerba, pada tanggal 12 Januari 2009 telah disahkan Undang-Undang Nomor 4 Tahun 2009 tentang Pertambangan Mineral dan Batubara (UU Minerba). Ini merupakan salah satu upaya untuk menegaskan kembali upaya pengelolaan sumber daya alam oleh Pemerintah sekaligus pula menegaskan kembali keberadaan Pasal 33 ayat (3) UndangUndang Dasar Tahun 1945, yang menyatakan bahwa "bumi, dan air, dan kekayaan alam yang terkandung di dalamnya dikuasai oleh negara dan dipergunakan untuk sebesar-besar kemakmuran rakyat". Seiring implementasinya, ternyata keberlakuan UU Minerba masih belum mampu menjawab beberapa permasalahan dan kebutuhan hukum di dalam pengelolaan minerba. Tercatat banyaknya kasus-kasus 
seperti tumpang tindih dan jumlah perizinan yang terlalu banyak serta tidak terkontrol, sinkronisiasi terhadap perundangundangan yang terkait, pencemaran lingkungan hidup, izin penggunaan lahan,sampai kriminalisasi dan keluhanan masyarakat sekitar daerah pertambangan atas oprasional perusahaan pertambangan. Semua kondisi tersebut telah direspon DPR RI dan Pemerintah Pusat dengan mencantumkan UU Minerba masuk di dalam Program Legislasi Nasional Prioritas Tahun 2015 pada urutan nomor 25.

Proses pembuatan danmuatan tiga undang-undang mengenai pemerintahan daerah selama era reformasi dipengaruhi oleh latar belakang sebagaimana digambarkan di atas. UU No. 22/1999, yang merupakan jawaban atas salah satu tunturan agenda reformasi, berisi desentralisasi yang dianggap paling liberal di dunia.Besarnya skala urusan pemerintahan yang dilimpahkan ke daerah menyebabkan UU tersebut dianggap mendekatkan Indonesia ke sistem pemerintahan federasi. Kementerian Dalam Negeri menganggap UU No. 22/1999 dominan dengan

desentralisasi.1 Pada saat yang sama desentralisasi di bidang pemberian izin pemanfaatan hutan dan usaha pertambangan dianggap menjadi penyebab banjir dan pencemaran air di sejumlah tempat di Sumatera, Kalimantan, Sulawesi, Maluku dan Papua. Alasan-alasan di atas kemudian melatari penggantian UU No. 22/1999 dengan No. 32/2004. UU yang terakhir ini dianggap memulai proses menarik kembali urusan pemerintahan yang sudah dilimpahkan ke daerah. Kementerian Dalam Negeri menganggap UU No. 32/2004 menghadirkan keseimbangan antara sentralisasi dan desentralisasi. UU No. 23/2014 yang diundangkan pada Oktober 2014, dianggap sebagai penyempurna proses sentralisasi yang sudah dimulai sejak UU No. 32/2004. Dalam bidang pengelolaan SDA UU 23/2014, menarik banyak urusan pemerintahan yang pernah dilimpahkan kepada kabupaten/kota lewat UU No. 23/2014 perubahan kewenangan kabupaten/kota di sektor kehutanan dan perikanan \& kelautan, mengakibatkan titik berat otonomi daerah di kabupaten/kota menjadi hapus. Kementerian Dalam Negeri beragumen bahwa sentralisasi tersebut ditujukan untuk mencapai pemerintahan yang efektif. Kemunculan UU No. 23/2014 (selanjutnya UU Pemda) dengan corak sentralistiknya menyisakan tanda tanya mengenai dampaknya terhadap undangundang di bidang sumberdaya alam seperti UU Kehutanan, UU Pengelolaan Wilayah Pesisir dan Pulau-Pulau Kecil (UUPWP\&PPK), UU Pertambangan Mineral dan Batubara (UU Pertambangan Minerba) dan UU Perikanan.

Keempat UU tersebut dinamai sebagai UU Sektoral. Selain terhadap UU Sektoral, UU Perlindungan dan Pengelolaan Lingkungan Hidup, juga menerima dampak dari pemberlakuan UU Pemda. Sejak tahun 1999, UU Sektoral dan UUPPLH telah menyesuaikan diri dengan UU No. 22/1999 dan No. 32/2004 dengan mengatur mengenai pembagian kewenangan. Pada saat yang sama, 
kementerian-kementerian yang melaksanakan undang-undang tersebut juga sudah menundukan diri pada peraturan pelaksana UU No. 22/1999 dan No. 32/2004 yang mengatur mengenai pembagian urusan pemerintahan antara pemerintah pusat, pemerintahan daerah provinsi dan pementahan daerah kabupaten/kota.

Adapun beberapa substansi di dalam UU Minerba yang harus menjadi fokus dan perhatian untuk dilakukan penyempurnaan adalah, pertama, paradigma penyelenggaraan minerba, kekayaan alam yang melimpah ruang di bidang minerba belum mampu dilindungi oleh regulasi yang sekarang ada. Potensi penerimaan Negara dari sektor minerba ditengarai banyak yang bobol karena pola kerjasama dengan pihak asing yang tidak menguntungkan, sehingga materi muatan perubahan UU Minerbaharus lebih berpihak kepada usaha Negara untuk mensejahterakan dan mengutamakan kepentingan rakyat sebagaimana termaktub di dalam Pasal 33 UUD NRI Tahun 1945. Selain itu, beberap substansi di dalam UU Minerba khususnya terkaitdengan kewajiban harus lebihdikedepankan.

Salah satunya mengenai pengolahan dan pemurnian minerba, yang kerap diekploitasi perusahaan asing untuk kemudian dieksport dalam bentuk mentah keluar negeri, akibatnya nilai tambah yang seharusnya dapat dinikmati oleh Indonesia justru beralih ke luar negeri. Di dalam perubahan UU Minerba nantinya, klausula mengenai kewajiban untuk membangun instalasi pengolahan dan pemurniaan (smelter) hendaknya ditegaskan kembali, jika perlu diberikan sanksi yang lebih tegas. Hal ini dilakukan untuk memberi nilai nilai tambah disektor minerba, sehingga pengaturan mengenai kewajiban pengolahan dan pemurnian yaitu semangat hilirisasi harus lebih diperkuat dan ditegaskan kembali dalam perubahan UU Minerba. Kedua, tindak lanjut Putusan Mahkamah Konstitusi (MK), dalam sejarah keberlakuannya, UU Minerba sudah beberapa kali dimohonkan untuk diuji terhadap UUD NRI Tahun 1945 oleh beberapa pemohon. Dari beberapa permohonan pengujian tersebut, tercatat 4 (empat) permohonan yang telah dikabulkan oleh MK baik itu secara sebagian atau secara keseluruhan.

Walaupun Putusan MK bersifat putusan yang menciptakan suatu keadaan hukum yang baru (constitutief) dan juga menyatakan suatu keadaan sebagai suatu keadaan yang sah menurut hukum (declatoir), tetapi putusan MK bersifat negative legislation, sehingga untuk itu setiap putusan MK seharusnya diresponoleh Pemerintah dan DPR RI sebagai pembentuk UU (positive legislation). Untuk itu di dalam perubahan UU Minerba nantinya, pasal-pasal yang telah mendapat judicial review oleh MK serta pasal-pasal terkait lainnya harus dirumuskan dan dikonstruksikan kembali di dalam perubahan UU Minerba, agar konsep pengaturannya menjadi lebih bulat dan mantap. Ketiga, sinkronisasi dengan Undang-Undang Nomor 23 Tahun 2014 tentang Pemerintahan Daerah (UU Pemda), dalam UU Pemda secara tegas dinyatakan, bahwa terkait urusan pemerintahan 
dibidang energi dan sumber daya mineral dibagi antara Pemerintah Pusat dan Pemerintah Provinsi (Pasal 14 ayat (1)). Selain itu, walaupun dalam urusan pemerintahan di bidang batu bara tidak dicantumkan secara tegas di dalam batang tubuh UU, tetapi bidang ini dimasukkan dalam lampiran UU Pemda yangmerupakan bagian tidak terpisahkan dari UU (Pasal 15 ayat (1)). Sehingga penyelenggaran urusan pemerintahan di bidang minerba dibagi antara Pemerintah Pusat dan Pemerintah Proivnsi. Disisi lain pembagian kewenangan terkait penyelenggaraan urusan

pemerintahan dibidang minerba yang ada di UU Minerba masih dibagi antara Pemerintah Pusat, Pemerintah Provinsi, dan Pemerintah Kabupaten/Kota. Sehingga dalam perubahan UU Minerba kedepan hal ini menjadi salah satu poin krusial yang menjadi agenda penting perubahan UU Minerba, agar terjadi sinkronisasi antara UU Minerba dengan UU Pemda dan tidak saling bertolak belakang, yaitu mengatur penyelenggaraan urusan pemerintahan di bidang minerba didalam perubahan UU Minerba menjadi bidang pemerintahan yang dipegang oleh Pemerintah Pusat dan Pemerintah Provinsi, sementara Pemerintah Kabupaten/Kota tidak lagi memiliki kewenangan.Walaupun begitu peran pemerintah daerah kabupaten kota tetapdiberikan porsi yang proporsional terkait dengan pengawasan wilayah pertambangan serta perizinan pertambangan dalam skala kecil/rakyat.

Keempat, izin. Terkait izin merupakan salah satu masalah yang paling pelik di dalam pengelolaan minerba. Kasus yang paling banyak ditemui terkait izin adalah tumpang tindihya izin di dalam satu wilayah yang sama, dalam arti terhadap satu wilayah pertambangan terdapat beberapa izin sehingga saling tumpang tindih. Hal ini tentu saja sangat merugikan pihak investor dan tidak menciptakan kepastian usaha. Disisi lain, Pemerintah Pusat yang seolah-olah lemah dan tidakmemiliki kewenangan untuk dapat menertibkan dan membatasi jumlah izin usaha pertambangan. Padahal usaha pembatasan perizinan sangat diperlukan tidak saja untuk memudahkan kontrol dari Pemerintah Pusat maupunPemerintah Daerah terhadappelaksanaan tahapan usaha pertambangan, tetapi juga untuk meminimalisir dari kerusakan lingkungan hidup sekaligus juga menyiapakan daerah pencadangan usaha pertambangan.

Untuk itu didalam perubahan UU Minerba nantinya harus ada materi-materi baru yang dapat mencegah atau meminimalisir tumpang tindih/duplikasi terhadap izin usaha pertambangan juga memperkuat kontrol pengawasan dan pembinaan oleh Pemerintah Pusat dan Pemerintah Daerah. Kelima, kriminalisasi masyarakat sekitar daerah pertambangan, hal ini berawal dari salah satu ketentuan dalam Pasal 162 UU Minerba, yang mengatur pidana bagi setiap orang yang merintangi atau mengganggu kegiatan usaha pertambangan dengan hanya merujuk kepada ketentuan Pasal 136 yang menyangkut penyelesaian hak atas tanah. Padahal disisi lain pemicu dari tindakan 
merintangi atau menghalangi yang dilakukan oleh masyarakat disekitar area pertambangan tidak hanya semata permasalahan hak atas tanah, tetapi juga karena tidak adanya mekanisme pengaduan oleh masyarakat terkait aspirasi mereka yang tidak tertampung atau tersalurkan melalui saluran yang ada, misalnya terhadap kasus-kasus pencemaran lingkungan atau masyarakat tidak merasakanlangsung manfaat dari adanyaperusahaan, disisi lain masyarakat merasa terganggu karena adanya potensi pemcemaran atau kebisingan sebagai dampak dari oprasionalperusahaan.

Untuk itu di dalam perubahan UU Minerba nantinya perlu ada klausula khusus yang mengatur pengecualian pengenaan sanksi pidana kepada masyarakat dalam hal kasus merintangi atau menghalangi yang berkaitan dengan kasus pencemaran lingkungan hidup. Hal ini akan sinkron pula dengan ketentuan di Pasal 66 UndangUndang Nomor 32 Tahun 2009 tentang Perlindungan dan Pengelolaan Lingkungan Hidup yang menyatakan "Setiap orang yang memperjuangkan hak ataslingkungan hidup yang baik dansehat tidak dapat dituntut secara pidana maupun digugat secara perdata". Selain itu, perlu juga ditambah ketentuan hak untuk mengajukan evaluasi, peninjauan, atau bahkan menolak oleh masyarakat disekitar wilayah pertambangan atas pertambangan yang akan dibuka diwilayah mereka, dalam hal keberadaan kegiatan pertambangan tersebut nyatanyata akan merugikan kepentingan masyarakat disekitar wilayah pertambangan. Keenam, kelestarian lingkungan hidup, banyak pelaku kegiatan usaha pertambangan kurang mengindahkan kaidah teknik pertambangan yang baik, terkait dengan aspek konservasi cadangan, kesehatan dan keselamatan kerja, dan pengelolaan lingkungan. Walaupun didalam UU Minerba telah ada ketentuan mengenai kewajiban reklamasi dan kegiatan pascatambang, tetapi dalam praktiknya masih ada wilayah pertambangan atau kegiatan pascatambang yang dibiarkan rusak tanpa ada usaha untukmengembalikan fungsi lahan kekondisi semula.

Hal ini terjadi karena lemahnya pengawasan dan pembinaan dari Pemerintah Pusat maupaun Pemerintah Daerah dalam melaksanakan ketentuan reklamasi dan kegiatan pasca tambang, selain itu kurangnnya keperdulian dan tanggungjawab pemilik izin pertambangan terhadap ketentuan reklamasi dan kegiatan pasca tambang karena sebagian darimereka sudah menitipkan dana jaminan reklamasi dan kegiatan pasca tambang. Untuk itu di dalam perubahan UU Minerba kedepan perlu diatur ketentuan mengenai penekanan atau kewajibanan untuk membiayai kerusakan lingkungan yang muncul akibat proses penambangan, juga sanksi baik itu yang bersifat administratif maupun pidana terhadap pelanggaran ketentuan kewajiban relamasi dan kegiatan pasca tambang kepada pemilik izin. Harapan Dimasa yang Akan Datang UU Minerba merupakan salah satu ujung tombak 
bagi pengaturan dalam pengelolaan minerba di Indonesia, untuk itu penyempurnaan UU Minerba tidak saja penting untuk dapat mengatur dan mengelola potensi kekayaan minerbanya, tetapi juga untuk memberikan landasan hukum bagi upaya pembenahan, penertiban, maupun pengawasan sekaligus juga pembinaan terhadap pengelolaan minerba di Indonesia.

Melihat urgensi yang telah diuraikan di atas terkait dengan perubahan paradigma dalam pengelolaan, sinkronisasi dengan UU Pemda terkait pembagian urusan kewenangan antara Pemerintah Pusat dan Pemerintah Daerah dalam pengawasan dan pembinaan pengelolan minerba, serta hal lain yang strategis menyangkut isu perizinan, lingkungan hidup, dan kepentingan langsung masyarakat di area pertambangan, nampaknya UU Minerba tidak hanya perlu dilakukan perubahan secara sebagai (parsial) tetapi harus dilakukan perubahan secara menyeluruh (penggantian), karena tidak saja substansi akan berubah lebih dari 50\% tapi juga sudah menyangkut perubahan paradigma di dalam pengelolaannya.

\section{Pengaturan Desentralisasi dalam Pengelolaan SDA}

Sejumlah UU sektoral di bidangSDA dan UU PPLH dibuat sebelum UU No 23/2014 (UU Pemda) diberlakukan. UU sektoral dimaksud adalah UU No. 41/1999 (UU Kehutanan),UU No.27/2007 tentang Pengelolaan Wilayah Pesisir dan PulauPulau Kecil sebagaimana telah diubah oleh UU No. 1/2014 (UU PWP\&PPK), UU No. 4/2009 tentang Pertambangan Mineral dan Batubara
(UU Minerba), UU No. 31/2004 tentang Perikanan sebagaimana telah diubah oleh UU No. 45/2009 (UU Perikanan). Dalam banyak hal, UU tersebut masih memuat semangat mendesentralisasi urusan pengelolaan SDA sebagai bagian dari kebijakan memberi otonomi kepada daerah untuk mengurus dan mengatur berdasarkan prakarsa sendiri. Pemberlakuan UU Pemda yang membawa semangat mengambil kembali urusan pemerintahan yang pernah dilimpahkan kepada kabupaten kota, tentu saja membawa pengaruh pada UU sektoral tersebut dengan cara memintanya menyesuaikan diri. Pengaruh UU Pemda terhadap UU sektoral dan UUPLH tidak hanya yang terkait dengan jenis-jenis urusan pemerintahan tetapi juga bentuk organisasi pemerintahan daerah.

Bagian ini memaparkan ketentuan mengenai desentralisasi bidang pengelolaan SDA sebagaimana diatur di dalam UU sektoral, UUPLH dan UU Pemda sendiri. Selain mendeskripsikan, bagian ini juga membuat analisis perbandingan antara UU Pemda dengan UU Sektoral dan UU PPLH. Tidak hanya sampai disitu, bagian ini juga menggambarkan implementasi UU Pemda sejauh ini sebagaimana tergambar surat edaran yang dibuat dan disebarluaskan oleh beberapa kementerian.

Batubara

Pertambangan Mineral dan

Undang-Undang Pertambangan

Minerba, terbit setelah 42 tahun sejak pertama kali urusan pertambangan diatur dalam UU No.11 Tahun 1967 tentang Pertambangan. Sama seperti 
UU PPLH, UU Pertabangan Minerba cukup lambat melakukan penyesuaian dengan UU Pemda. Sebagai pengganti dari UU Pertambangan No.11 Tahun 1997, UU Pertambangan Minerba menegaskan bahwa 1). Mineral dan batubara sebagai sumber daya yang tak terbarukan dikuasai oleh negara dan pengembangan serta pendayagunaannya dilaksanakanoleh Pemerintah dan pemerintah daerah bersama dengan pelaku usaha; 2).

Pemerintah selanjutnya memberikan kesempatan kepada badan usaha yang berbadan hukum Indonesia, koperasi, perseorangan, maupun masyarakat setempat untuk melakukan pengusahaan mineral dan batubara berdasarkan izin, yang sejalan dengan otonomi daerah, diberikan oleh Pemerintah dan/atau pemerintah daerah sesuai dengan kewenangannya masing-masing; 3). Dalam rangka penyelenggaraan desentralisasi dan otonomi daerah, pengelolaan pertambangan mineral dan batubara dilaksanakan berdasarkan prinsip eksternalitas, akuntabilitas, dan efisiensi yang melibatkan Pemerintah dan pemerintah daerah; 4). Usaha pertambangan harus memberimanfaat ekonomi dan sosial yang sebesarbesar bagi kesejahteraan rakyat Indonesia; 5).

Usaha pertambangan harus dapat mempercepat pengembangan wilayah dan mendorong kegiatan ekonomi masyarakat/pengusaha kecil dan menengah serta mendorong tumbuhnya industri penunjang pertambangan; 6). Dalam rangka terciptanya pembangunan berkelanjutan, kegiatan usaha pertambangan harus dilaksanakan dengan memperhatikan prinsip lingkungan hidup, transparansi, dan partisipasi masyarakat. UU Pertambangan Minerba, mengatur pembagian kewenangan pemerintah, pemerintah provinsi dan pemerintah kabupaten/kota sebagai berikut: (Pasal 6, Pasal 7 dan Pasal 8)

Kewenangan Pemerintah dalam pengelolaan pertambangan mineral dan batubara, antara lain, adalah: a. penetapan kebijakan nasional; b. pembuatan peraturan perundang-undangan; c. penetapan standar nasional, pedoman, dan kriteria; d. penetapan sistem perizinan pertambangan mineral dan batubara nasional; e. penetapan WP yang dilakukan setelah berkoordinasi dengan pemerintah daerah dan berkonsultasi dengan Dewan Perwakilan Rakyat Republik Indonesia; f. pemberian IUP, pembinaan, penyelesaian konflik masyarakat, dan pengawasan usaha pertambangan yang berada pada lintas wilayah provinsi dan/atau wilayah laut lebih dari 12 (dua belas) mil dari garis pantai; g. pemberian IUP, pembinaan, penyelesaian konflik masyarakat, dan pengawasan usaha pertambangan yang lokasi penambangannya berada pada lintas wilayah provinsi dan/atau wilayah laut lebih dari 12 (dua belas) mil dari garis pantai; h. pemberian IUP, pembinaan, penyelesaian konflik masyarakat, dan pengawasan usaha pertambangan operasi produksi yang berdampak lingkungan langsung lintas provinsi dan/atau dalamwilayah laut lebih dari 12 (dua belas)mil dari garis pantai; i. pemberian IUPK Eksplorasi dan IUPK Operasi Produksi; j. pengevaluasian IUP 
Operasi Produksi, yang dikeluarkan oleh pemerintah daerah, yang telah menimbulkan kerusakan lingkungan serta yang tidak menerapkan kaidah pertambangan yang baik; k.penetapan kebijakan produksi, pemasaran, pemanfaatan, dan konservasi; 1 . penetapan kebijakan kerja sama, kemitraan, dan pemberdayaan masyarakat; $\mathrm{m}$. perumusan dan penetapan penerimaan negara bukan pajak dari hasil usaha pertambangan mineral dan batubara; n. pembinaan dan pengawasan

\section{penyelenggaraan}

pengelolaan pertambangan mineral dan batubara yang dilaksanakan oleh pemerintah daerah; o. pembinaan dan pengawasan penyusunan peraturan daerah di bidang pertambangan; $p$. penginventarisasian, penyelidikan, dan penelitian serta eksplorasi dalam rangka memperoleh data dan informasi mineral dan batubara sebagai bahan penyusunan WUP dan WPN; q. pengelolaan informasi geologi, informasi potensi sumber daya mineral dan batubara, serta informasi pertambangan pada tingkat nasional; r. pembinaan dan pengawasan terhadap reklamasi lahan pascatambang; s. penyusunan neraca sumber daya mineral dan batubara tingkat nasional; $t$. pengembangan dan peningkatan nilai tambah kegiatan usaha pertambangan; dan u. peningkatan kemampuan aparatur Pemerintah, pemerintah provinsi, dan pemerintah kabupaten/kota dalam penyelenggaraan pengelolaan usaha pertambangan.
Kewenangan pemerintah provinsi dalam pengelolaan pertambangan mineral dan batubara, antara lain, adalah: a. pembuatan

peraturan perundang-undangan daerah; b. pemberian IUP,pembinaan, penyelesaian konflik masyarakat dan pengawasan usaha pertambangan pada lintas wilayah kabupaten/kota dan/atau wilayah laut4 (empat) mil sampai dengan 12 (duabelas) mil; c. pemberian IUP, pembinaan, penyelesaian konflik masyarakat dan pengawasan usaha pertambangan operasi produksi yang kegiatannya berada pada lintas wilayah kabupaten/kota dan/atau wilayah laut 4 (empat) mil sampaidengan 12 (dua belas) mil; d. pemberian IUP, pembinaan, penyelesaian konflik masyarakat dan pengawasan usaha pertambangan yang berdampak lingkungan langsung lintas kabupaten/kotadan/atau wilayah laut 4 (empat) mil sampai dengan 12 (dua belas) mil; e. penginventarisasian, penyelidikan dan penelitian serta eksplorasi dalam rangka memperoleh data dan informasi mineral dan batubara sesuai dengan kewenangannya; f. pengelolaan informasi geologi, informasi potensi sumber daya mineral dan batubara, serta informasi pertambangan pada daerah/wilayah provinsi; g. penyusunan neraca sumber daya mineral dan batubara pada daerah/wilayah provinsi; $h$. pengembangan dan peningkatan nilai tambah kegiatan usaha pertambangan di provinsi; i. pengembangan dan peningkatan peran serta masyarakat dalam usaha pertambangan dengan memperhatikan kelestarian lingkungan; j. pengoordinasian perizinan dan pengawasan penggunaan bahan peledak diwilayah tambang sesuai dengan kewenangannya; $\mathrm{k}$. penyampaian informasi hasil inventarisasi, 
penyelidikan umum, dan penelitian serta eksplorasi kepada Menteri dan bupati/walikota; 1. penyampaian informasi hasil produksi, penjualan dalam negeri, serta ekspor kepada Menteri dan bupati/walikota; $\mathrm{m}$. pembinaan dan pengawasan terhadap reklamasi lahan pascatambang; dan

n. peningkatan kemampuan aparatur pemerintah provinsi dan pemerintah kabupaten/kota dalam penyelenggaraan pengelolaan usaha pertambangan.

Kewenangan pemerintah kabupaten/kota dalam pengelolaan pertambangan mineral dan batubara, antara lain, adalah: a. pembuatan peraturan perundang-undangan daerah; b. pemberian IUP dan IPR, pembinaan, penyelesaian konflik masyarakat, dan pengawasan usaha pertambangan di wilayah kabupaten/kota dan/atau wilayah laut sampai dengan 4 (empat) mil; c. pemberian IUP dan IPR, pembinaan, penyelesaian konflik masyarakat dan pengawasan usaha pertambangan operasi produksi yang kegiatannya berada di wilayah kabupaten/kota dan/atau wilayah laut sampai dengan 4 (empat) mil; d. penginventarisasian, penyelidikan dan penelitian, serta eksplorasi dalam rangka memperoleh data dan informasi mineral dan batubara; e. pengelolaan informasi geologi, informasi potensi mineral dan batubara, serta informasi pertambangan pada wilayah kabupaten/kota; f. penyusunan neraca sumber daya mineral dan batubara pada wilayah kabupaten/kota; g. pengembangan dan pemberdayaan masyarakat setempat dalam usaha pertambangan dengan memperhatikan kelestarian lingkungan; h. pengembangan dan peningkatan nilai tambah dan manfaat kegiatan usaha pertambangan secara optimal; i. penyampaian informasi hasil inventarisasi, penyelidikan umum, dan penelitian, serta eksplorasi dan eksploitasi kepada Menteri dan gubernur; $j$. penyampaian informasi hasil produksi, penjualan dalam negeri, serta ekspor kepada Menteri dan gubernur; $k$. pembinaan dan pengawasan terhadap reklamasi lahan pascatambang; dan 1. peningkatan kemampuan aparatur pemerintah kabupaten/kota dalam penyelenggaraan pengelolaan usaha pertambangan. (2) Kewenangan pemerintah kabupaten/kota sebagaimana dimaksud pada ayat (1) dilaksanakan sesuai dengan ketentuan peraturan perundangundangan.

Kewenangan yang cukup nyata bagi Pemerintah Kabupaten/Kota dalam bidang Pertambangan Mineral dan Batubara diwujudkan dalam bentuk antara lain: - kewenangan dalam penerbitan izin usaha pertambangan (IUP) dan izin usaha pertambangan rakyat(IUPR) membentuk struktur satuan kerja perangkat daerah (dinas pertambangan) - menyusun peraturan daerah (Perda) yang berhubungan dengan pertambangan.

Sebagaimana dijelaskan pada bagian Pendahuluan, UU No. 23/2014 tentang Pemerintahan Daerah (UU Pemda) bercorak sentralistik. Sekalipun Kementerian Dalam Negeri menyebut UU ini memiliki tujuan menciptakan penyelenggaraan pemerintahan yang efektif, ketentuan dan penjelasan di dalamnya menyiratkan kehendak 
untuk memusatkan kembali penyelenggaraan pemerintahan. Untuk menjustifikasi penyelenggaraan pemerintahan sentralistk tersebut, UU ini membangun sejumlah argumen mengenai asal-usul kekuasaan pemerintahan. UU ini berargumen bahwa dalam negara kesatuan, pemerintah pusat lah yang pertama kali mendapatkan kekuasaan pemerintahan. Kekuasaan tersebut kemudian dibagibagi ke pemerintah daerah.

Oleh karena itu pemerintah daerah berada di bawah pembinaan dan pengawasan pemerintah pusat dalam menyelenggarakan urusan pemerintahan. Dikatakan juga bahwa tanggungjawab akhir penyelenggaraan pemerintahan ada pada pemerintah pusat sebagai sumber asal kekuasaan pemerintahan. UU Pemda secara konsisten menampakan ekspresi sentralisme penyelenggaraan pemerintahan ketika merumuskan ketentuan-ketentuan mengenai penyerahan kewenangan (desentralisasi). Secara umum, UU Pemda menarik secara signifikan kewenangan pengelolaan SDA dari kabupaten/kota. Dalam bidang kehutanan, hanya pengelolaan taman hutan raya yang masih tersisa di daerah. Sebagian kewenangan ditarik ke pusat atau dilimpahkan ke provinsi.

Perubahan lebih drastisterjadi pada sektor kelautan. UUPemda tidak menyisakan satukewenangan pun kepada

kabupaten/kota untuk pengelolaan sumberdaya laut. Desentralisasi pengelolaan sumberdaya laut hanya sampai di tingkat provinsi. Tidak seperti di sektor kelautan, pada sektor perikanan, kabupaten/kota masih memiliki kewenangansekalipun lebih banyak untuk urusan pemberdayaan nelayan kecil. Urusan lainnya adalah pengelolaan dan penyelanggaraan Tempat Pelelangan Ikan (TPI) dan menerbitkan izinperikanan budidaya. Kewenangan yang diberikan ke provinsi banyak menyangkut perizinan selain pengawasan sumberdaya perikanan.Untuk bidang energi dan sumberdaya mineral, UU Pemda masih memberikan kewenangan kepada provinsi dan kabupaten/kota sepanjang tidak mengenai minyak dan gas bumi.

\section{Perbandingan Undang-undang Pemerintahan Daerah dengan Undang-undang Sektoral}

Dengan diterbitkan pengganti UU 32 Tahun 2004 tentang Pemerintahan Daerah oleh UU 23 Tahun 2014, pembagian urusan pemerintahan menjadi salah topik penting dan menarik perhatian banyak pihak. Pembagian urusan pemerintahan menjadi penting bagi Pemerintah Kabupaten/Kota karena menyangkut kewenangan apa saja yang masih dipegang dengan terbitnya UU Pemda yang baru tersebut. Dalam suatu acara seminar nasional di Bulan Maret 2015, di Kalimantan Timur, dengan topik bahasan adalah materi UU Pemda yang baru, mengundang banyak komentar utamanya dari Pemerintah Kabupaten/Kota. Pokok argumentasinya, adalah bakal hilangnya sebagian bersar kewenangan pemerintah kabupaten/kota khususnya pada bidang kehutanan, pertambangan dan 
kelautan. Nada kekecewaan begitu tampak dari komentar danpertanyaan para wakil pemerintah kabupaten/kota. Khusus pada bidang kehutanan dan pertambangan, implikasi penerapan UU 32 Tahun 2014 akan menyebabkan hilangnya dinas kehutanan dan dinas pertambangan. Sebab, tidak signifikan bagi Pemerintah Kabupaten/Kota untuk membentuk SKPD Kehutanan dan Pertambangan jika wewenang atau hal yang diurus hanya 1 (satu) urusan. Misalnya di bidang kehutanan, Pemerintah kabupaten/kota hanya berwenang mengurus Taman Hutan RayaPaparan berikut membandingkan ketentuan UU Pemda dengan beberapa UU sektoral (UU Kehutanan, UU PWP\&PPK, UU Pertambangan Minerba, UU Perikanan) dan UU PPLH terkait dengan desentralisasi pengelolan SDA. (Tahura), sedangkan di bidang energy dan sumber daya mineral hanya mengurus penerbitan izin pemanfaatan langsung panas bumi dalam daerah kabupaten/kota.

\section{Implementasi Undang-undang Pemerintahan Daerah}

UU Pemda menghendaki perubahan penyelenggaraan pemerintahan di tingkat daerah. Penyelenggaraan pemerintahan dengan pembagian kewenangan seperti yang diinginkan oleh UU Pemda, ditargetkan harus sudah berjalan dua tahun setelah UU tersebut diberlakukan. Masa waktu dua tahun digunakan untuk mempersiapkan pelaksanaan UU Pemda secara penuh. Untuk memastikan persiapan tersebut berjalan dengan baik dan sesuai target waktu, sejumlah Menteri mengeluarkan surat edaran yang ditujukan kepada pemerintah daerah. Tujuannya untuk mengingatkan ketentuan-ketentuan dalam UU Pemda yang menginginkan Pemda melakukan langkah-langkah persiapan, dan memberikan arahan mengenai tindakan dan perubahanperubahan yang perlu dilakukan dalam rangka menyambungkan antara situasi/perbuatan yang sudah dilakukan sebelumnya dengan ketentuan dalam UU Pemda.

Bagian-bagian berikut akan memaparkan perbuatan administratif oleh sejumlah kementerian (pemerintah pusat) dalam rangka melaksanakan UU Pemda dalam bentuk membuat surat edaran. Sebagai kementerian yang bertanggung jawab atas pelaksanaan UU Pemda, Kementerian Dalam Nageri yang dalam hal ini diwakili oleh Menteri, membuat dan menyebarkan Surat Edaran yang ditujukan kepada Gubernur dan Bupati/Walikota seIndonesia. Surat Edaran tersebut bertanggal 16 Januari 2015.2 Pada intinya surat edaran tersebut mengatur mengenai 4 hal yaitu: (i) langkah-langkah yang perlu dilakukan dalam rangka penyerahan penyelenggaraan urusan pemerintahan; (ii) bagaimana melaksanakan tindakan-tindakan masa transisi; (iii) tindakan-tindakan sementara menunggu terbentuknya perangkat di tingkat daerah yang permanen. Tindakan-tindakan yang disarankan dilakukan untuk penyerahan penyelenggaraan urusan pemerintahan misalnya serah terima personil, pendanaan, saran dan prasarana serta dokumen (P3D) yang harus dituntaskan dalam dua tahun. 
Surat edaran menyarankan untuk melakukan inventarisasi P3D sebelum melakukan serah terima. Saran lainnya agar Gubernur dan Bupati/Walikota melakukan koordinasi diantara mereka termasuk koordinasi DPRD dan Kementerian relevan. Dalam rangka menyelenggarakan urusan pemerintahan umum, surat edaran memberi petunjuk agar Badan/Kantor Kesbangpol dan atau biro/bagian di sekretariat daerah yang membidangi urusan pemerintahan menanganinya, sementara menunggu terbentuknya instansi vertikal yang akan membantu gubernur dan bupati/walikota.

$\begin{array}{ccr}\text { Adapun } & \text { saran untuk } \\ \text { menyelenggarakan } & \text { tugas } & \text { dan }\end{array}$ wewenang Gubernur sebagai wakil pemerintah pusat, surat edaran memberi petunjuk untuk menugaskan SKPD provinsi menunggu terbentuknya perangkat Gubernur. Sekitar empat bulan setelah surat edaran Menteri Dalam Negeri, Menteri Lingkungan Hidup dan Kehutanan, membuat dan menyebarluaskan sebuah surat edaran yang ditujukan kepada Gubernur, Bupati/walkota dan kepala dinas yang membidangi urusan kehutanan provinsi dan kabupaten/kota.3 Dengan menyebut ulang sejumlah ketentuan dalam UU Pemda, surat edaran tersebut memperjelas implikasi pemberlakuan UU Pemda pada kewenangan penyelenggaraan izin dan pelayanan publik. Kewenangan-kewenangan tersebut yang menurut peraturan perundangan sebelumnya (PP 38/2007) menjadi milik kabupaten/kota, beralih kepada provinsi menurut UU Pemda. Hal menarik dari surat edaran tersebut bahwa peralihan penyelenggaraan kewenangan tersebut secara otomatis terjadi dengan pemberlakuan UU Pemda. Salah satu contoh yang disebutkan dalam surat edaran tersebut bahwa peralihan tersebut bersifat otomatis adalah pemberian izin perhutanan sosial yaitu izin usaha hutan kemasyarakatan, hak pengelolaan hutan desa dan izin usaha pemanfaatan hasil hutan kayuhutan tanaman rakyat. Surat edaran tersebut menentukan bahwa bagi yang sudah ada penetapan areal oleh Menteri Lingkungan Hidup dan Kehutanan, izin diberikan oleh Bupati dengan mempertimbangkan tahapan dan proses yang sudah dilakukan oleh Bupati/walikota.

\section{Analisis dampak Pemberlakuan Undang-undang Pemerintahan Daerah}

Undang-undang emerintahan Daerah baru berlaku kurang lebih setahun, dampak pemberlakuan yang dipaparkan dalam laporan ini belum merupakan hal-hal yang konkrit seperti penambahan jumlah UPTD provinsi atau penghapusan sauan kerja perangkat daerah tingkat kabupaten/kota.

Denganbaru melewati kurang lebih satu tahun, paparan mengenai dampak lebih menunjuk pada pandangan-pandangan terhadap UU Pemda dan rencana-rencana mengimplementasikannya.Pandanga npandangan mencakup optimisme dan kekawatiran-kekawatiran mengenai kondisi dan hasil yang akan muncul.

\section{Organisasi perangkat daerah}


$\begin{array}{lr}\text { Sekalipun } & \text { mendapatkan } \\ \text { tambahan kewenangan yang banyak } \\ \text { dari pemberlakuan UU Pemda, } \\ \text { pemerintah provinsidi tempattertentu } \\ \text { kawatir dengan kemampuan mereka } \\ \text { dengan jumlah sumberdaya manusia } \\ \text { yang terbatas. } & \text { Dicontohkan } \\ \text { kemampuan untuk } & \text { menangani } \\ \text { permohonan izin } & \text { usaha }\end{array}$ pertambangan yang mencapai 700an. Situasi yang sama juga dibayangkan berpotensi terjadi untuk penyelenggaraan perizinan di bidang kehutanan. Pemerintah diperkirakan tidak akan bisa menyediakan pelayanan efektif akibat banyaknya jumlah permohonan apalagi harus melakukan verifikasi lapangan ke tempat-tempat yang secara jarak jauh dari ibu kota provinsi. 4 Karena itu, kehadiran Unit Pelaksana Teknis (UPT) Kementerian di daerah, dianggap akan bisa mengatasi kelemahan tersebut.

\section{Kesimpulan}

Implikasi dari perubahan

Undang-undang Pemerintahan Daerah diantaranya berkurangnya kewenangan Pemerintah Daerah Tinggkat II berkaitan Pemberian izin dan Pengawasan Pemanfaatan Energi dan Sumber Daya Alam yang ada di kawasan Daerah Kabupaten/kota di Indonesia. pengambilan kebijakan publik (public policy making). Energi dan Sumberdaya mineral saat ini telah memainkan peran sangat penting dalam pembangunan pereekonomian Indonesia, yang berfungsi sebagai salah satu tulang punggung penerimaan Negara. Pengelolaannya Sumber Daya Alam perlu dilakukan secara optimal, efisien, transparan, berkelanjutan dan berwawasan lingkungan, serta berkeadilan agar dapat memperoleh manfaat sebesar-besar bagi kemakmuran rakyat secara berkelanjutan.

\section{Saran}

1. Perlunya Peninjauan ulangaturan berkaitan dengan pengurang kewenangan Pemerintah Daerah Khusunya Pemerintah Kabupaten Kota berkaitan dengan Pemanfaatan Energi dan Sumber DayaMineral.

2. Pemerintah dalam hal ini sebagai Penyelengara dari Tata Kelola Energi dan Sumber DayaMineral harus dapat membuat dan mempercepat berkaitan dengan energi terbarukan sebagai pengganti Energi Sumber Daya Mineral habis pakai

3. Pemerintah dalam pemanfaatan Energi dan Sumber DayaMineral harus bisa efektif, efesien, transparan dan tepat sasaran bagi kemajuan bangsa dan kemakmuran masyarakat.

\section{Daftar Kepustakaan}

Bratakusumah, Supriady, Dedi dan Solihin, Dadang. 2001. Otonomi Penyelenggaraan Pemerintah Daerah. Jakarta: Gramedia Pustaka Utama.

D. Siregar, Doli. 2002. Optimalisasi Pemberdayaan Harta Kekayaan Negara. Jakarta: Gramedia Pustaka Utama. Islamy, A.Irvan. 1994. Prinsip-prinsip Perumusan Kebijakan Negara, Jakarta: Bina Aksara. Edisi 2, Cet. 1. Kaho, Josef Riwu, 1991. Prospek Otonomi Daerah di Negara RI. Jakarta: Rajawali Press. 
Sabar, Eko Prihatin. 2009. Otonomi Daerah dan Pengelolaan Sumber Daya Alam. Semarang: Fakultas

Suharto, Edi. 2005. Membangun Masyarakat Memberdayakan Rakyat.Bandung: Refika Aditama.

Winarno, Budi. 2007. Kebijakan Publik Teori \& Proses . Yogyakarta: Media Pressindo. Yasmi, Yardi. Dkk. 2005. Kompleksitas Pengelolaan Sumber Daya Hutan di Era Otonomi Ekosistemik dalam Daerah; Studi Kasus di Pengelolaan Sumberdaya Kabupaten Sintang 30 Alam di Daerah, Makalah disampaikan dalam "Seminar Internasional IV Dinamika Politik Lokal di Indonesia: Partisipasi dan Demokrasi", Salatiga, 14-18 Juli 2003. Kalimantan Barat. Bogor: Inti Prima Karya.

di Keamatan, M. P. N. S., \& Hulu, S. Evaluasi Pelaksanaan Peraturan Pemerintah Nomor 45 Tahun 2007 Tentang Persyaratan dan Tata Cara Pengangkatan Sekretaris Desa.

Ispik, A., Yogia, M. A., Wedayanti, M. D., \& Zainal, Z. (2021). The Influence of Discipline on Performance of Employees Office of the Ministry of Religion. Pekanbaru City.

Subhayano, T., Yogia, M. A., Wedayanti, A. A. P. M. D., \& Zainal, M. L. H. (2021). Good Governance in Maintaining Peace and Order at Pangkalan Kerinci District. Pelalawan Regency.

Ispik, A., Yogia, M. A., Purwati, A.
A., Wedayanti, M. D., \& Zainal, M. L. H. (2021). Analysis of Benefits, Discipline and Leadership Style in improving Employee Performance of the Ministry of Religion in Pekanbaru, Indonesia.

Nasri, H., Nurman, N., Azwirman, A., Zainal, Z., \& Riauan, I. (2022). Implementation of collaboration planning and budget performance information for special allocation fund in budget planning in the regional development planning agency of Rokan Hilir regency. International Journal of Health Sciences (IJHS) Ecuador, 6(S4), 639-651.

Munir, A., Wahyudi, S., \& Zainal, Z. (2020). Tinjauan Kriminologi Terhadap Sensual Marketing Sebagai Strategi Pemasaran Produk Yang Diperankan Oleh Sales Promotion Girl Di Kota Pekanbaru. Wedana: Jurnal Kajian Pemerintahan, Politik dan Birokrasi, 6(2), 21-35.

Subhayano, T., Yogia, M. A., Wedayanti, M. D., \& Zainal, Z. (2021). The Role of the Camat in Coordinating the Administration of Peace and Order in Pangkalan Kerinci District Pelalawan Regency.

Suwaryo, H. U., \& Redjo, H. S. I. (2018). Transformasi Hubungan Pemerintah Pusat Dan Pemerintah Daerah Dalam Pemberian Izin Hutan Tanaman Industri Bagi Swasta Di Provinsi Riau Tahun 2010-2015.

Wicaksono, A. (2022, April). 
Peatlands Restoration Policies in Indonesia: Success or Failure?. In IOP Conference Series: Earth and Environmental Science (Vol. 995, No. 1, p. 012068). IOP Publishing.

Yogia, A. S. M. A., Rahman, Z. M. D. W. K., \& Purwati, A. A. (2021). Leadership of Tourism and Culture Department in Development of Cultural Reserves at District Kuantan Singingi.

Zainal, Z., Rambey, R. R., \& Rahman, K. (2021). Governance of Household Waste Management in Pekanbaru City. MIMBAR: Jurnal Sosial dan Pembangunan, 37(2).

Halim, N. A., Rosidi, I., Haris, A., Yesicha, C., \& Riauan, M. A. I. Media dan Politik.

Riauan, M. A. I., Aziz, A., \& Nurman, N. (2020). Analisis Framing" Aksi Bela Islam" sebagai Dakwah Islam di Riau Pos (A Framing Analysis of" Islam Defense Action" as Islamic Dakwah on Riau Pos Newspaper). Jurnal Dakwah Risalah, 31(1), 35-47.

Riauan, M. A. I., Qurniawati, E. F., Aslinda, C., \& Aziz, A. (2020). Konstruksi Realitas Pada Pesan Politik Calon Walikota Pekanbaru di Riau Pos. ETTISAL: Journal of Communication, 5(1).

Riauan, M. A. I., Kholil, S., \& Sikumbang, A. T. (2019). Islamic Symbols on Political Messages in Newspapers in Riau (Study in Regional Head Election 2017). Budapest International Research and Critics Institute-
Journal (BIRCI-Journal), 2(1), 254-262.

Riauan, M. A., Sari, G. G., Aslinda, C., \& Qurniawati, E. F. (2018). Konstruksi Makna Ketergantungan dalam Perilaku Merokok. Relasi Negara Industri Dan Masyarakat Dalam Perspektif Komunikasi, 171.

Riauan, M. A. I., \& Shasrini, T. (2017). Dampak Komunikasi Terapeutik terhadap Citra Pelayanan Kesehatan (Studi Kasus di Rumah Sakit Umum Daerah Arifin Achmad Pekanbaru). Jurnal The Messenger, 9(1), 31-43.

Riauan, M. A. I. (2016). Figur Politik Calon Walikota Pekanbaru Septina Primawati Rusli dan Erizal Muluk Pada Pemilukada Kota Pekanbaru 2011. Medium, 4(2).

Riauan, M. A. I. (2013). Penggunaan Teknologi Komunikasi dalam Penerapan Good Governance. Jurnal Kajian Pemerintahan, 2(2), 102-107.

Riauan, M. A. I. (2012). Studi Komparatif Aktivitas Humas Antara Pemerintah Provinsi Riau dengan PT.Chevron Pacific Iindonesia. Medium, 1(1).

Sari, G. G., Wirman, W., \& Riauan, M. A. (2018). Pergeseran Makna Tradisi Bakar Tongkang Bagi Generasi Muda Tionghua di Kabupaten Rokan Hilir Provinsi Riau. 